Research Article

\title{
Factors Related to the Number of Antral Follicles on In-Vitro Fertilization (IVF)
}

\author{
Faktor yang Terkait dengan Jumlah Folikel Antral pada Fertilisasi in Vitro
}

Fransiskus C Raharja, Ketut Suwiyoga, IPG Wardhiana

Department of Obstetrics and Gynecology

Faculty of Medicine University of Udayana/

Sanglah General Hospital

Bali

\begin{abstract}
Objective: To determine factors which are related to the number of antral follicles on infertile patients.

Method: This cross sectional study was conducted in In-Vitro Fertilization (IVF) clinic of Graha Tunjung, Sanglah hospital, Bali. All fertile patients following the IVF program were calculated the number of antral follicles in both ovarian using transgene USG. This sample was recruited by random sampling from April 1st, 2001 to April 30th, 2011. We analyzed the data using Chi square test through SPSS for Windows 17.0 version.
\end{abstract}

Result: Of 102 samples, the mean of patients' age was 32.9\% (SD 4.6) years old. From 72 patients (70.6\%) experienced above 3 years of infertile period, the primary infertile was on 69 patients $(67.7 \%)$. There was a relationship between patients' age and the number of antral follicles significantly (prevalence ratio (PR) 1.41 ; 95\% CI 1.111.79). Meanwhile, the number of antral follicles and type of infertile (PR 1.02; 95\% CI 0.76-1.37) also infertile period (PR 0.95; 95\% CI $0.72-1.27$ ) were not associated significantly.

Conclusion: Patients' age has an association with the number of antral follicles on IVF.

[Indones J Obstet Gynecol 2016; 4-2: 75-77]

Keywords: age, infertile, infertile period, number of antral follicles and type of infertile

\begin{abstract}
Abstrak
Tujuan: Mengetahui faktor yang berhubungan dengan jumlah folikel antral pada pasien infertil.

Metode: Studi potong lintang ini dilaksanakan di Klinik Bayi Tabung Graha Tunjung, RSUP Sanglah, Bali. Sampel penelitian ini adalah semua pasien infertil yang mengikuti program fertilisasi in vitro dengan menghitung jumlah folikel antral pada kedua ovariumnya menggunakan USG transvaginal. Pengambilan sampel dilakukan dengan cara random sampling mulai dari 1 April 2001 hingga 30 April 2011. Analisis data memakai uji Chi Square dengan bantuan SPSS untuk windows versi 17.0.
\end{abstract}

Hasil: Dari 102 sampel penelitian rerata usia pasien adalah 32,9\% $(S D 4,6)$ tahun. Pasien yang mengalami infertil lebih dari 3 tahun adalah $72(70,6 \%)$ orang dengan infertil primer sebanyak $69(67,7 \%)$ orang. Terdapat hubungan antara usia ibu dengan jumlah folikel antral secara bermakna (PR 1,41; IK 95\% 1,11-1,79). Tidak terdapat hubungan antara jenis infertil dengan jumlah folikel antral (PR 1,02; IK 95\% 0,76-1,37). Tidak terdapat hubungan antara lama infertil dengan jumlah folikel antral (PR 0,95; IK 95\% 0,72-1,27).

Kesimpulan: Usia pasien berhubungan dengan jumlah folikel antral pada fertilisasi in vitro.

[Maj Obstet Ginekol Indones 2016; 4-2: 75-77]

Kata kunci: infertile, jumlah folikel antral, lama infertile, tipe infertile dan usia

Correspondence. Fransiskus C Raharja, Jln. Tukad Batanghari V/10, Renon, Denpasar. obginz@gmail.com, Telephone: 081236367577

\section{INTRODUCTION}

Infertility is defined as not getting pregnant (conceive) after one year of unprotected intercourse. Nowadays, it becomes the concern of many married couple. A survey conducted by Statistics Centre Agency in 1995, the infertility rate in Indonesia was $12 \%$.

Assisted Reproductive Technology (ART), especially in-vitro fertilization (IVF) or well-known as "test tube baby" is one way to solve the infertility in advanced. Unfortunately, there are several factors influencing the success of this IVF such as age, infertility period, and type of infertility. ${ }^{1,2}$
The advanced technology in IVF has enabled us to assess how much the possibility of success gained on every patients and it can determine the proper time to follow the program. It is very important to perform a diagnostic examination based on evidence based to escalate the chance to get pregnant. The easy and important examination to predict the success of stimulating ovarian is the number of antral follicles. Meta-analysis study reported that the number of antral follicles was an excellent predictor in ovarian stimulation. The increase of age was associated with the number of antral follicles; however, study carried out in San Francisco rejected this statement. ${ }^{1,3,4}$ 
According to the previous results above, this study aims to determine factors contributing to the number of antral follicles to increase the success rate of IVF.

\section{METHOD}

This cross sectional study was conducted in IVF clinic of Graha Tunjung, Sanglah Hospital, Bali. All fertile patients following the IVF program were calculated the number of antral follicles in both ovarian using transgene USG. This sample was recruited by random sampling from April $1^{\text {st }}, 2001$ to April 30 ${ }^{\text {th }}$, 2011. We analyzed the data using Chi square test through SPSS for Windows 17.0 version.

\section{RESULTS}

Of 102 infertile patients joining to the IVF program in IVF Graha Tunjung Sanglah Hospital Bali, the mean of age was 32.9 (SD 4.6) years old and the infertile period was 6.1 (SD 4.0) years.

Table 1 explained the relationship of age, type of infertile, and infertile period with the number of antral follicles on IVF. From Chi-square test, only age had association with the number of antral follicles with prevalence ratio (PR) 1.41 (95\% CI 1.111.79; $\mathrm{p}=0.016$ ).

\section{DISCUSSION}

The result showed that 45 patients (44.1\%) younger than 36 years old had less than 10 antral follicles on IVF and only 29 patients (28.4\%) had more than 10 follicles. Other study pointed out that the number of antral follicles on young female was 3-11 per ovarian. Antral follicles calculated for superovulation process on both ovarian were the primordial follicles which would be developed to be- come a mature follicle. The ideal number of antral follicles on both ovaries after IVF was 11-30 follicles; less than 5 follicles signed poor response and more than 30 follicles indicated excellent response.

The older the patients are, the less possibility to get conceive. A study revealed that before 24 years old, the fertility rate of women reached $100 \%$ and it decreased gradually as the increase of age and finally, after 50 years old, the fertility rate became $0 \%$. Another study showed that women would experience the decrease of fertility at 37.5 years old, whereas the pregnancy rate over 1 year under 31 year-old women was $74 \%$ and they fell into $54 \%$ above 35-year old women. ${ }^{1,3-7}$ This fact is due to the lack number of primordial follicles. The acceleration loss of follicle occurred at 37 years old and raised after 10 to 12 years of menopause. The number of antral follicles sized $\geq 2 \mathrm{~mm}$ which was assessed by transvaginal USG decreased $60 \%$ between 22 and 42 years old. In accordance with the number of antral follicles, the ovum quantity and quality was worsened started from 30 years old and much more after 40 years old.

The impaired of fecundity increased from $2 \%$ at the age of $15-19$ years old to $28 \%$ at the age of more than 35 years old. ${ }^{6}$ The decrease number of antral follicles was in parallel to the decrease in the quality of the oocyte. Similar study had been conducted showing that there was a relationship between age and the number of antral follicles, which there was a decrease in the number of antral follicles from 0.35 to 0.95 per year. According to a study in India, it had been found that the difference in the number of antral follicles were associated with age probably because there were differences in race and geography of the region. There was a significant decrease in fertility in line with the increase of age. Around 11\% women did not get

Table 1. Relationship of Age, Type of Infertile, and Infertile Period with the Number of Antral Follicles on IVF.

\begin{tabular}{|c|c|c|c|c|c|c|}
\hline \multirow{2}{*}{\multicolumn{2}{|c|}{ Characteristics }} & \multicolumn{2}{|c|}{ Number of Follicles } & \multirow[b]{2}{*}{ PR } & \multirow[b]{2}{*}{$95 \% \mathrm{CI}$} & \multirow[b]{2}{*}{$\mathbf{p}$} \\
\hline & & & & & & \\
\hline \multirow[b]{2}{*}{ Age } & $>36$ years old & 24 & 4 & \multirow[b]{2}{*}{1.41} & \multirow[b]{2}{*}{$1.11-1.79$} & \multirow[b]{2}{*}{0.016} \\
\hline & $\leq 36$ years old & 45 & 29 & & & \\
\hline \multirow{2}{*}{ Type of Infertile } & Primary & 47 & 22 & \multirow[b]{2}{*}{1.02} & \multirow[b]{2}{*}{$0.76-1.37$} & \multirow[b]{2}{*}{0.884} \\
\hline & Secondary & 22 & 11 & & & \\
\hline \multirow{2}{*}{ Infertile period } & $>3$ years & 48 & 24 & \multirow{2}{*}{0.95} & \multirow{2}{*}{$0.72-1.27$} & \multirow{2}{*}{0.743} \\
\hline & $\leq 3$ years & 21 & 9 & & & \\
\hline
\end{tabular}


pregnant after 40 years old and $87 \%$ was infertile at 45 years old. ${ }^{8-11}$

The result from this study revealed that the type of infertility did not affect the number of antral follicles as either primary or secondary infertility in married couples. It was clearly showed that the number of antral follicles did not have an association with the type of infertility because one year did not describe how long the couple was married and tried to get pregnant. It could happen at 25year-old women who would not like to have a child after one year of marriage although they had good number of antral follicles. Apart from that, other same age women who suffered from diseases, for example Polycystic Ovarian Syndrome (PCOS), had many number of antral follicles, but it looked the small size. The duration of infertility did not provide information on whether the problem either in male or only female, even both of them. There might be heavy biological problem if the duration was longer than 3 years. ${ }^{12-18}$

\section{CONCLUSION}

Patients' age has an association with the number of antral follicles on IVF.

\section{REFERENCES}

1. Wardhiana IPG. Penanganan infertilitas dasar. Naskah Lengkap Pendidikan Kedokteran Berkelanjutan Obstetri dan Ginekologi FK UNUD/RS Sanglah Denpasar. 2004.

2. Wald TV, Thornton K. Assisted reproductive technology in vitro. In: Lewis V, editors. Reproductive Endocrinology and Infertility. Texas: Landes Bioscience; 2007: 178-87.

3. Tran ND, Cedars MI, MC Culloch et al. A longitudinal study questions the accepted relationship between antral follicle count (AFC) and age. Fertil Steril. (serial online). [cited 2011 Juni 3]. Available from: http://www.fertstert.org/article/ S0015-0282(09)02396-6/abstract. 2009

4. Hendriks DJ, Kwee J, Mol BW et al. Ultrasonography as a tool for the prediction of outcome in IVF patients: A comparative meta-analysis of ovarian volume and antral follicle count. Fertil Steril. (serial online). [cited 2011 Juni 3]. Available from: URL:http://www.fertstert.org/article/ S00150282\%2806\%29043779/abstract. 2007.
5. Ng EHY, Tang OS, Ho PC. The Significance of the number of antral follicles prior to stimulation in predicting ovarian response in an IVF programme. Hum Reprod. (serial on-line). [cited 2011 Juni 3]. Available from: URL: http://www.humrep.oxfordjournals.org/content/15/9/1937.short.2000.

6. Halim B, Anwar I, Adenin I. Penilaian fungsi ovarium. In: Darmasetiawan S, Anwar I, Djuwantono T, Adenin I, Jamaan, T, editors. Fertilisasi in Vitro dalam Praktek Klinik. $1^{\text {st }}$ Ed. Jakarta: Puspa Swara; 2006: 59-84.

7. Toner JP. Testing ovarian reserve in vitro. In: Gardner DK editors. In Vitro Fertilization A Practical Approach. New York: Informa Health Care Inc; 2007: 30-7.

8. Torrente SL, Rice VM. An Overview of female infertility. In: Lewis V. Reproductive Endocrinology and Infertility. USA: Landes Bioscience; 2007: 145.

9. Baziad A. Endokrinologi ginekologi. edisi ketiga. Jakarta. Media Aesculapius. Fakultas Kedokteran Indonesia; 2008: 225.

10. Djuwantono T, Permadi W, Herlianto H, Halim D. Apa itu infertilitas? In: Djuwantono T, Permadi W, Herlianto $\mathrm{H}$, Halim D, editors. Hanya 7 Hari Memahami Infertilitas. $1^{\text {st }}$ Ed. Bandung: Refka Aditama. 2008: 1-8.

11. Kumar A, Ghadir S, Eskandari $\mathrm{N}$ et al. Infertility. In: Decherney AH, Nathan L, Goodwin TH, Laufer N editors. Current Diagnosis and Treatment Obstetrics and Gynecology. 10 $0^{\text {th }}$ ed. US: McGraw Hill Companies; 2007: 917-8.

12. Kartina N. Infertilitas. (serial online). [cited 2011 Juni 3]. Available from: URL: http://permatacibubur.com/en/jurnal antral/see.php.htm. 2011.

13. Wongso AD. Male Infertility - Andrology. (serial online). [cited 2011 Juni 3]. Available from: URL: http://www.klinik andrologi.blogspot.com. 2007.

14. Speroff L, Fritz MA. Clinical gynecologic endocrinology and infertility. Wolters Kluwr; 2011: 1138 -90.

15. Almog B, Shehatta F, Shalom EW et al. Age-related Normogram for Antral Follicle Count: McGill Reference Guide. Fertil Steril. (serial online), Febuary, [cited 2013 Juni 3]. Available from: URL:http: //www.fertstert.org/article/ S00150282(10)02461-1/abstract. 2011.

16. Agarwal A, Verma A, Agarwal S et al. Antral follicle count in normal (fertility-proven) and infertile indian women. Ind J Radiol Imag. (serial online), Agust, [cited 2014 Des 3]. Available from: URL: http://www.ijri.org. 2014.

17. Hestiantoro A. Konsensus penanganan infertilitas. Himpunan Endokrinologi Reproduksi dan Fertilitas Indonesia; 2013: 6-12.

18. Moini A, Shafizadeh N, Dastjerdi V et al. The effect of age on ovarian reserve markers in Tehranian women with normal fertility. Int J Endocrinol Metab; 2008: 2. 